\title{
Changes in the margin of Ice Stream C, Antarctica
}

\author{
R.W. Jacobel, ${ }^{1}$ T. A. Scambos, ${ }^{2}$ N. A. Nereson, ${ }^{3}$ C. F. Raymond ${ }^{3}$ \\ ${ }^{1}$ Department of Physics, St Olaf College, Northfield, Minnesota 55057, U.S.A. \\ ${ }^{2}$ National Snow and Ice Data Center, CIRES, University of Colorado, Boulder, Colorado 80309-0449, U.S.A. \\ ${ }^{3}$ Geophysics Program, University of Washington, Seattle, Washington 98195-1650, U.S.A.
}

\begin{abstract}
We present results from satellite imagery, ice-motion surveys and icepenetrating radar studies of part of the north margin of Ice Stream C, one of the ice streams draining the West Antarctic ice sheet to the "Ross Embayment". Our studies suggest that the shutdown of Ice Stream C about 150 years ago was not a single event, but a sequence involving stagnation of ice and migration of the ice-stream boundary. Ground-based studies confirm the inference from imagery that a series of former shear zones exist, decreasing in age towards the ice-stream center. A region of ice-stream trunk, including a former margin, lies sheared and folded between the (recent) inner and (older) outer margins of the area. Icemotion and topographic surveys give some constraint on the time of shutdown of the outer margin. The results provide a forum for discussing shutdown mechanisms. Possible causes for the stepwise migration of the north margin of Ice Stream C include a gradual decrease in ice flux, a reduction in the available water or hydrostatic pressure in the basal till, or a freezing of the till layers on the northern side.
\end{abstract}

\section{INTRODUCTION}

Drainage of the West Antarctic ice sheet (WAIS) is controlled by ice streams which deliver most of the mass flux to the bounding ice shelves. In the "Ross Embayment", Ice Streams A-E drain the interior in a dynamic system that has changed in both flux and configuration over a range of temporal and spatial scales. Four of the ice streams are currently active, while Ice Stream C stagnated approximately 150 years ago (Shabtaie and Bentley, 1987; Retzlaff and Bentley, 1993), leading to questions about the conditions necessary to sustain rapid ice motion and the relationship of this event to other changes in the drainage configuration from the ice sheet. At the millennial scale, the system has lost approximately twothirds of its mass since the end of the last glacial epoch (Bindschadler, 1998). In the nearer term, both ice-stream velocities and ice-stream widths are observed to fluctuate on a scale of years to decades at rates of $1-2 \%$ per year for ice speed, and $0.1 \%$ per year for width (e.g. Alley and Whillans, 1991; Bohlander and Scambos, 1997; Bindschadler and Vornberger, 1998). This suggests that ice streams may be constantly adjusting to local changes in basal lubrication and evolving at their margins.

Additional evidence for change at an intermediate timescale has come from the morphology preserved in the icesheet surface and the adjacent ice shelf. An assessment of surface features associated with ice flow (e.g. "scars", flow bands, and a host of shear-related features on the ice shelf) suggests that both mass flux and the fundamental configuration of the ice streams have changed several times during the last few centuries (Fig. 1; see also Stephenson and Bindschadler, 1988; Casassa and others, 1991; Scambos and Bindschadler, 1991; Scambos and Nereson, 1996; personal communication from M. A. Fahnestock, 1998). Scar features (marking former ice-shear margins) and relict flowlines (marking former ice-stream trunk areas) are present in several areas that are no longer rapidly flowing. These morphological features have been revealed through the use of satellite images, as more sophisticated processing techniques have been applied to extract the maximum amount of surface detail available in digital images (e.g. Orheim and Lucchitta, 1987; Bindschadler and Vornberger, 1990; Kvaran and others, 1996). The initial, image-based interpretation of the features in several areas has now been confirmed by radio-echo sounding and other data, resulting in the discovery of the "Fishhook" extension of Ice Stream B (Bentley and others, 1994; personal communication from I. M. Whillans and G. Hamilton, 1999) and a new relict ice-stream outlet trunk, "Siple Ice Stream" (Jacobel and others, 1996a). Several areas have yet to be surveyed, but bear similar features that suggest past changes in the margins of Ice Stream B and the southern side of Ice Stream C. However, not all scars represent former shear margins, as recent evidence from Roosevelt Island indicates (Conway and Gades, in press).

Knowledge of the evolution of the ice streams is essential for understanding the response of the WAIS to environmental change and for gauging the overall contribution of the WAIS to sea-level rise, both in the past and in the future. We report here on image- and ground-based studies of a group of scar features on the north side of Ice Stream C and discuss their implications for the causes of its shutdown. We have called this area the "Duckfoot" because of the splayed pattern of traces present in satellite imagery (Fig. 2).

\section{GROUND-BASED STUDIES OF THE SIPLE DOME AREA}

St Olaf College, the University of Washington and the University of Colorado were involved in ground-based studies of the Siple Dome area in 1994 and 1996. These studies combined ice-penetrating radar and global positioning system 


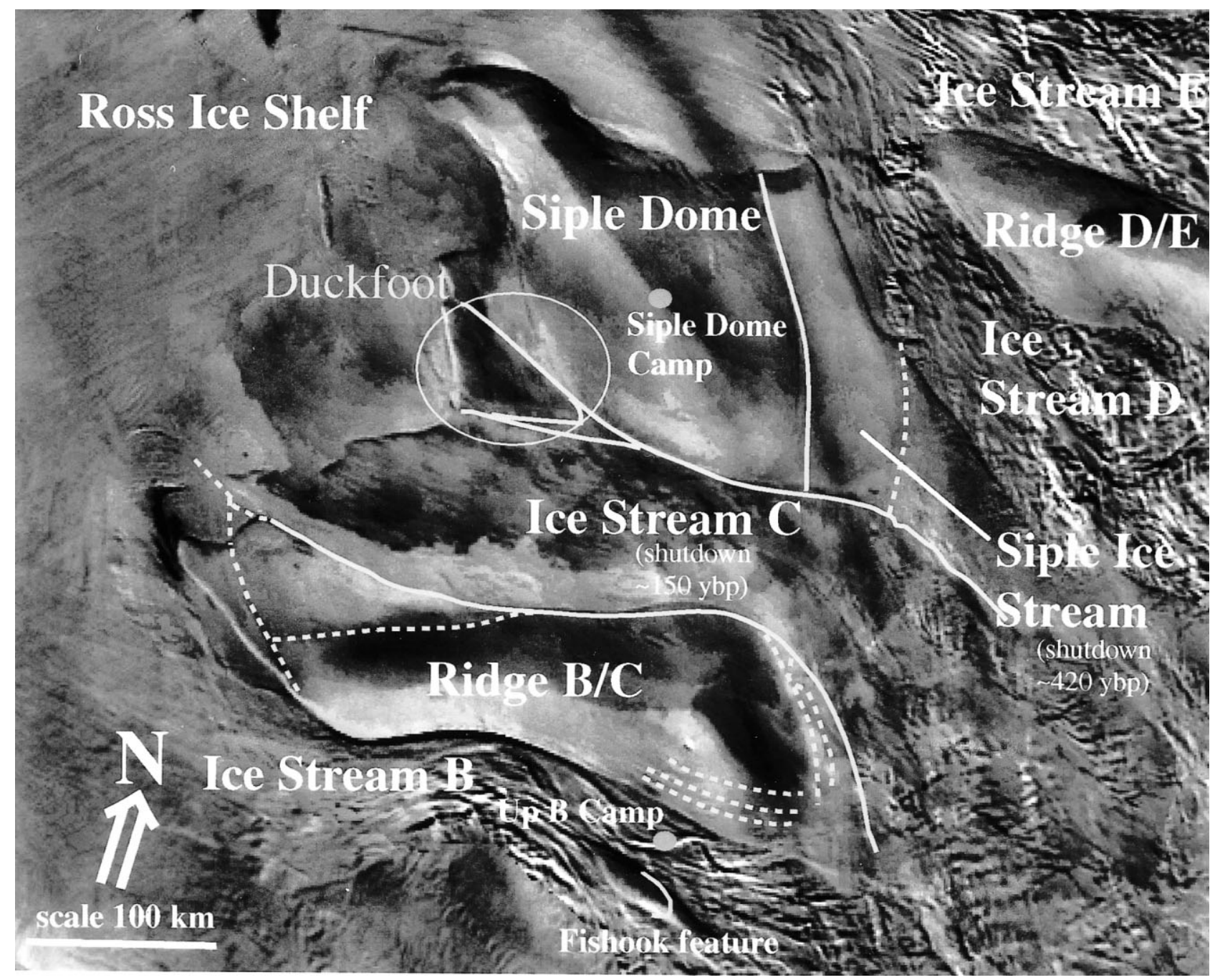

Fig. 1. Overview of the central Siple Coast from a mosaic of AVHRR images. Confirmed former shear margins are shown as solid lines; scars of suspected margins are shown as dotted lines. The south flank of Siple Dome and the Duckfoot margin scars described in this study are highlighted.

(GPS) measurements of surface displacement to characterize the current and past ice flow in the vicinity of the summit and flanks of the dome. Radar echoes from "internal layers", atmospheric deposits on the surface which are subsequently buried, show the ice deformation and flow history as described in more detail below. This work has been motivated by two related goals: a desire to understand the dynamics and history of ice flow in the area, and to use this as an aid in the siting and interpretation of a core drilled to the bed beneath Siple Dome in 1997-99. Figure 2 is a detail of the Siple Dome area from enhanced Advanced Very High Resolution Radiometer (AVHRR) imagery showing the bounding ice streams and surface features which are related to changes in the ice flow discussed below. Also shown are the location of the core, and the radar/GPS traverses.

Radar and GPS data at the summit have been used to characterize the geometry (Raymond and others, 1995; Jacobel and others, 1996b) and mass balance of Siple Dome. Modeling work based on these studies has been used to describe ice flow in the vicinity of the divide, in particular to predict the agedepth relation (Nereson and others, 1996), and to investigate the history of the divide location (Nereson, 1998; Nereson and others, 1998a, b). Figure 3 shows the results of the full radar profile across Siple Dome and adjacent margins. Data across the central part of the dome are at $2 \mathrm{MHz}$ center frequency of the impulse transmitter, while data at the margins are at a somewhat higher resolution with $5 \mathrm{MHz}$ center fre- quency. Siple Dome is approximately $1 \mathrm{~km}$ thick at the summit, and overlies a bedrock plateau. Internal layering is well resolved down to about two-thirds of the ice thickness beneath the dome summit, and to levels considerably below that on the south. The layers are continuous from one side of the dome to the other, but the pattern is interrupted on both flanks, to the north by the relict margin of Siple Ice Stream, and to the south by a series of disruptions at the Duckfoot discussed in more detail below. Layers are arched upward directly beneath the dome summit due to local flow and mass-balance anomalies at the divide, and the fact that to first order, the divide location has remained stable, as discussed by Nereson and others (1998a). The north-south asymmetry of the more recent layers in the upper half of the ice thickness is likely the result of an accumulation gradient, also discussed in Nereson and others (1998a).

Radar and GPS traverses of the scar feature to the north show an abrupt disruption of the deeper internal layers (below about $100 \mathrm{~m}$ depth) which otherwise trace continuously back to the summit (Fig. 3). This disruption is coincident with the scar feature and also an abrupt change in the reflection characteristics of the bed (not well depicted in the figure) possibly associated with the presence of water in a till layer (Gades, 1998). These results confirm that the scar is the surface expression of the margin of a relict ice stream which we have called Siple Ice Stream that once crossed this flank of Siple Dome (Jacobel and others, 1996a). This paper 


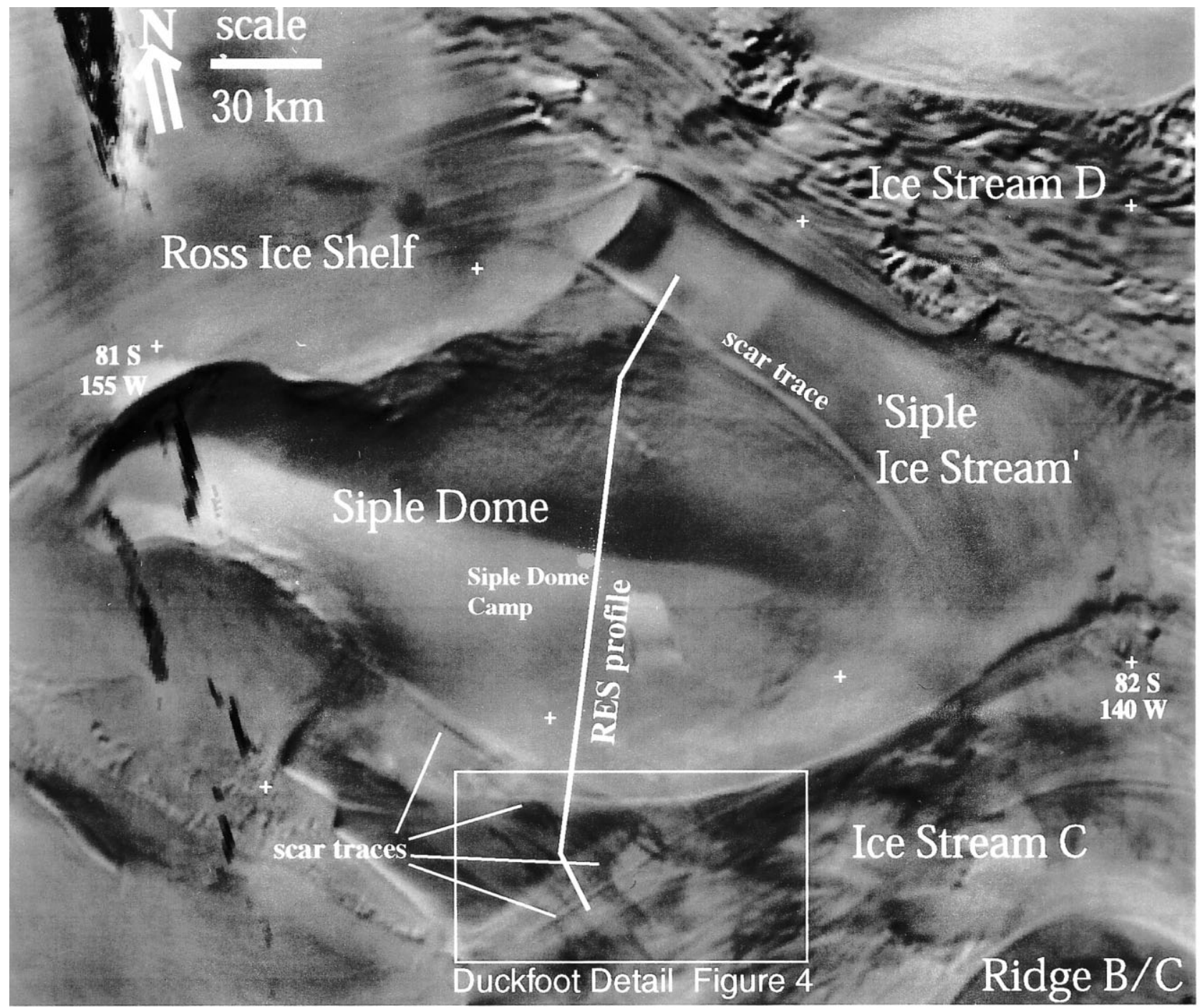

Fig. 2. Detail of Siple Dome and surrounding Ice Streams C and D and the relict Siple Ice Stream from enhanced AVHRR imagery. White lines indicate the paths of radar and GPS traverses. Several of the scar traces have been confirmed as former icestream margins as described in the text. RES, radio-echo sounding.

focuses on radar, GPS and satellite-imagery studies of the south flank of Siple Dome, and in particular on features at the former margin of Ice Stream C.

\section{THE DUGKFOOT AREA}

The south flank of Siple Dome terminates at the margin of Ice Stream $\mathrm{G}$ where satellite imagery (Fig. 2 and, in more detail, Fig. 4) reveals a splayed pattern of margin scars and flow bands we have called the Duckfoot. Investigations of the opposite margin on the south side of Ice Stream C during the late 1980s showed that rapid flow ceased approximately simultaneously along most of the lower trunk as determined by the burial depth of crevasses (Retzlaff and Bentley, 1993). Based on these depths and the known accumulation rate, Retzlaff and Bentley dated the shutdown of C as having occurred $130 \pm 25$ years prior to their study. Shallower burial depths at one location near the far upstream end of their survey indicated that shutdown there was more recent.

Satellite imagery of the north margin of $\mathrm{C}$ suggests a more complex series of events. Figure 4 shows a detail of the Duckfoot region derived from an enhanced Landsat Thematic Mapper (TM) scene. Several margin scars and flow bands are revealed by low-angle sun illumination of breaks in slope. The scar representing the most recent margin of Ice Stream C enters Figure 4 adjacent to an older margin (bright band) at the top of the figure. Toward the center of the image it diverges at about $20^{\circ}$ from the old margin and traverses diagonally, becoming less distinct toward the bottom right of the figure. At that point a series of flow bands merges with it in a tight "V" pattern. Tracing these flow bands upstream, they wrap tightly around a central raised (bright) area between the older and the most recent margin scars. An additional scar, considerably broader than the other two (up to $6 \mathrm{~km}$ wide), is visible in the enhanced AVHRR image of Figure 2 crossing the southwest flank of Siple Dome. It is not apparent in the Landsat image of Figure 4 because the sun direction is along the feature.

Figure 5 shows the results of the GPS survey across the lower part of the south flank of Siple Dome (Nereson, 1998, 2000). Continuous kinematic data were obtained in 1996 to define the topographic surface, and fast-static surveys of a series of 29 poles were acquired in 1996 and repeated in 1997 to obtain velocities. As expected, downslope velocities relative to the summit pole increase gradually to about $2 \mathrm{~m} \mathrm{a}^{-1}$ near km 36 as the surface slope increases, and thereafter velocities decrease rapidly, as depicted in Figure 5. The prominent middle scar of the Duckfoot (Fig. 2) is crossed by the survey at $\mathrm{km} 61$, after which the slope abruptly decreases 


\title{
SIPLE DOME
}

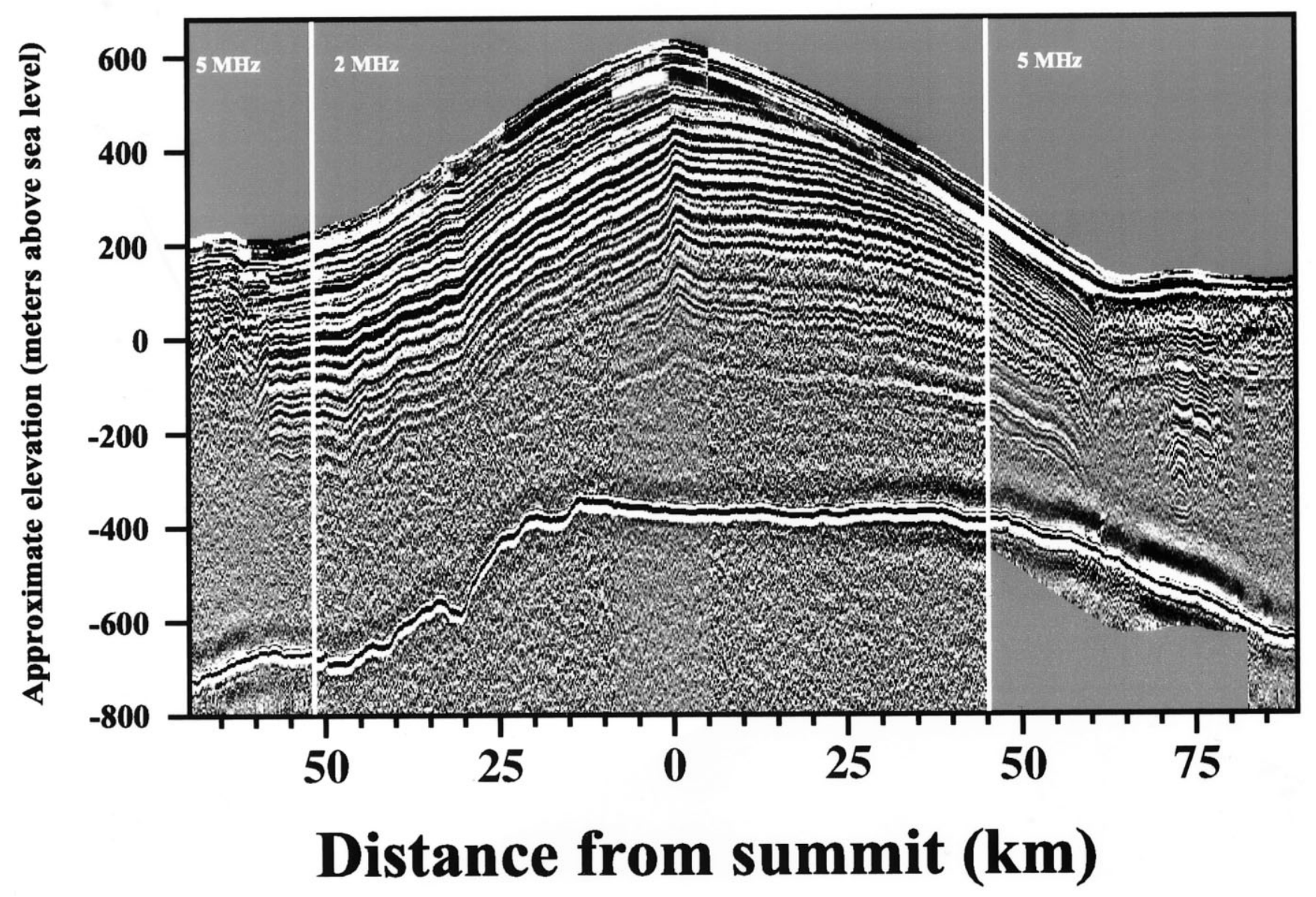

\begin{abstract}
Fig. 3. Radar profile across Siple Dome and bounding ice-stream margins with a vertical exaggeration of approximately 70. View is approximately toward the east, with Ice Stream Cand the Duckfoot margin on the right and the relict Siple Ice Stream on the left. Distances are relative to the Siple Dome summit location. Data across the margins were acquired at $5 \mathrm{MHz}$ center frequency of the transmitter for increased resolution. Scars depicted in the satellite imagery correspond to breaks in the surface slope and disruption of the internal stratigraphy at approximately $\mathrm{km} 60$ north of the summit (left) and at several locations beyond $\mathrm{km} 60$ to the south as described in the text.
\end{abstract}

to zero and the velocity drops below $0.5 \mathrm{~m} \mathrm{a}^{-1}$. Beyond this point, the velocity remains essentially constant at about $0.25 \mathrm{ma}^{-1}$, a value which approaches the resolution of the 1 year velocities. The overall pattern of strain rates is therefore strongly compressive from $\mathrm{km} 42$ to $\mathrm{km} 61$ of the traverse, and modeling studies by Nereson (1998) show that velocities along the south flank are not consistent with steady-state flow; the ice is thickening rapidly. Also, the lack of obvious strain anomalies across the lower $25 \mathrm{~km}$ indicates that the scars and flow bands in the Duckfoot could not have been created by the present flow regime. Thus they are clearly relict features which contain clues about the shutdown of Ice Stream C.

The lower panel of Figure 6 is a detail of the Duckfoot region showing surface elevations obtained by GPS and the radar results. The upper panel shows part of the Landsat image of Figure 4 at the same scale for comparison. The prominent east-west-trending margin scar in the satellite image is coincident with a break in surface slope and a sharp trough in the internal layers of the radar image at $\mathrm{km} 61$. Deeper layers below the trough fold strongly toward the bed, and a line of near-bed diffractors, probably crevasses, runs sub-parallel to the scar, offset toward Ice Stream G by about two ice thicknesses. The mechanism responsible for this downwarping may be melting near the ice-bed interface as discussed by Raymond and others, (1997). The coincidence of the surface break in slope, the bed diffractors and anomalies in the internal layer geometry strongly suggests that the scar defines a former margin. We also have data from a second traverse (Fig. 2) across the scar, parallel to this one and offset by approximately six ice thicknesses, giving some indication of the three-dimensional structure of the area. The sharp trough in the internal layers, downwarping deeper internal layers and bed crevasses seen in the lower panel of Figure 6 are all evident at approximately the same locations in this traverse as well. The northernmost broad scar seen in Figure 2 is crossed by both profiles (approximately km 55 in Fig. 6), but only a barely discernible break in surface slope is observed, with no disruption of the internal layers or change in bed reflectivity.

The remainder of the radar section in Figure 6 depicts zones where internal layers are well defined (but deformed), separated by sections where they are highly disturbed. Presumably this corresponds to regions of the former ice stream that have experienced moderate deformation in contrast to those where large shearing has occurred. For the purposes of the discussion we have labeled these regions 1-5 in Figure 6, starting at the outermost area on the north directly beneath the scar. In 


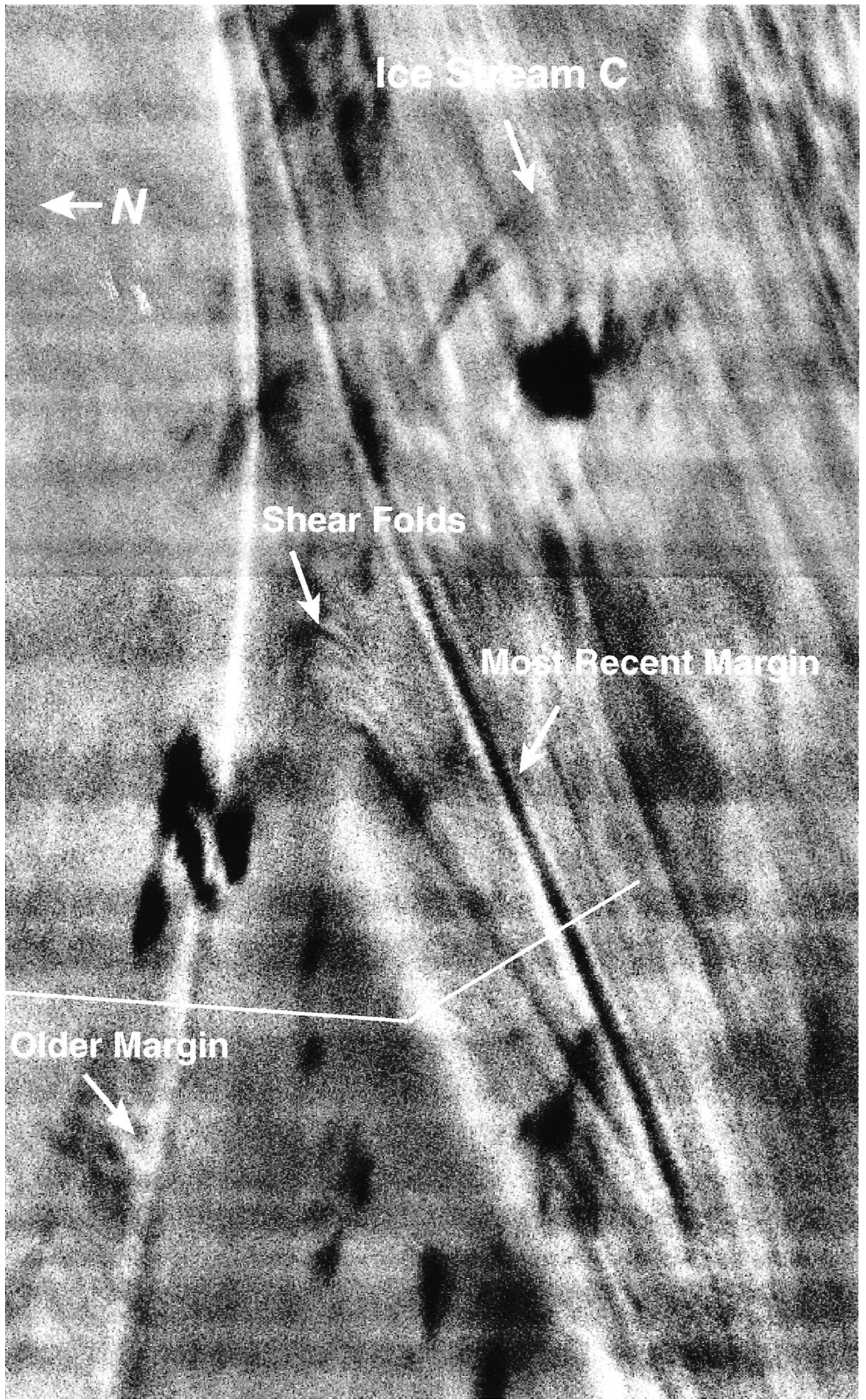

Fig. 4. Detail of the Duckfoot scars and flow bands from two enhanced Landsat TM scenes. Resolution of the image is $28.5 \mathrm{~m}$ per pixel, and the sun azimuth is approximately southeast (from the upper right in the image). The location of the radar and GPS traverse is indicated by the white line. 


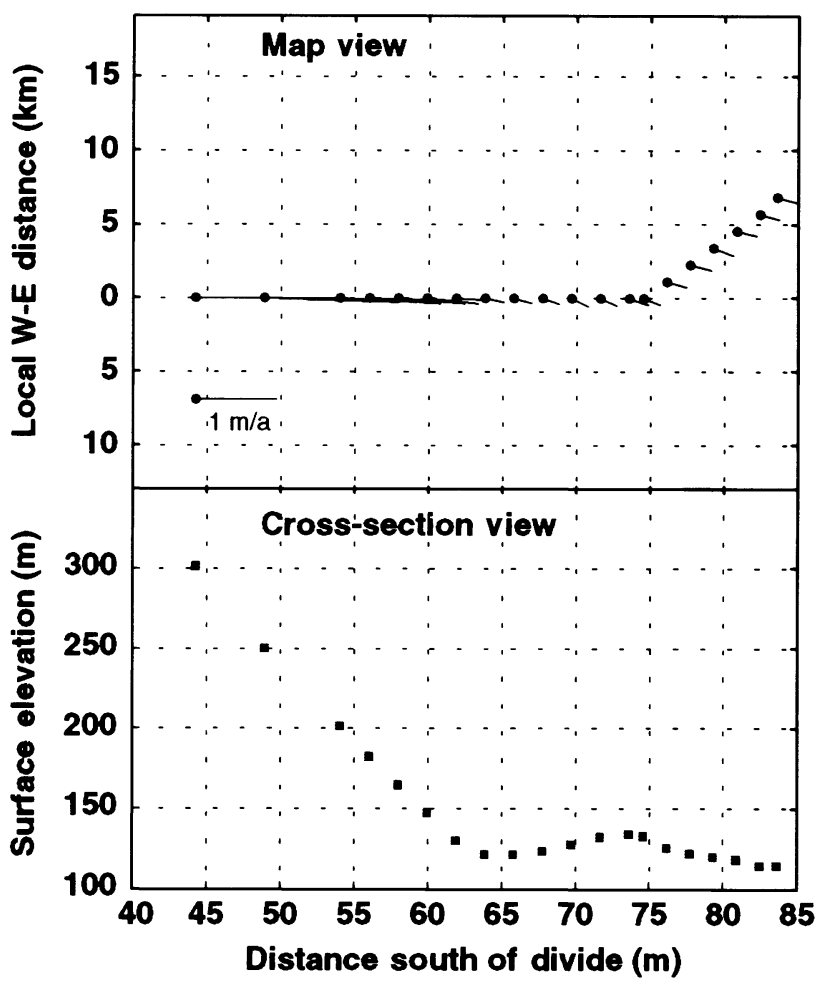

Fig. 5. GPS results showing surface topography and downslope velocities along the lower part of the south flank of Siple Dome. The origin of coordinates is the Siple Dome summit.

region 2, internal layers are discernible for approximately another $6 \mathrm{~km}$ past the scar/trough before becoming lost in the diffractors. This implies that shear was accommodated across a fairly broad margin zone located somewhat inboard from the surface scar and the underlying downwarp in the internal layers. The reason for this offset is not clear.

The surface above region 2 is a broad trough which rises to a ridge of amplitude $\sim 15 \mathrm{~m}$ near $\mathrm{km} 75$, about $14 \mathrm{~km}$ south of the scar. The crest and south slope of this ridge corresponds to the bright area in the satellite image between folded flow bands. Beneath the ridge in region $3(\mathrm{~km} 71-$ 79 ) is a zone of well-defined internal layers bearing no simple relationship to those under Siple Dome. Deformation in the lower layers within the zone does not match well with that above. The ice/bed interface below zone 3 is the brightest anywhere along the traverse. Further south, a second break in the internal layers of $\sim 2.5 \mathrm{~km}$ (region 4 ) is followed by another zone of well-defined internal layers (region 5, km 82-84) not continuous with the first. Diffractors predominate beyond this as the traverse enters the most recently active part of Ice Stream C.

The presence of near-surface diffractors southward of the trough/break in slope of region 1, which continue all the way into the ice stream, indicates crevassing and argues that this area was all formerly part of Ice Stream C. Also, the region of well-defined internal layers (region 3, km 7179 ) in Figure 6 shows undulating internal layering typical of ice-stream ice (Jacobel and others, 1993). The second region of well-defined internal layers (region 5, $\mathrm{km} \mathrm{82-84)} \mathrm{is} \mathrm{also}$ distinct from the areas which surround it. If these two areas of well-defined internal layers were indeed formerly parts of Ice Stream C, then the layer pattern in Figure 6 depicts a shift of the north margin of Ice Stream C, ultimately leading to the shutdown.

\section{WHAT MADE THE DUGKFOOT?}

Whatever scenario emerges to account for the detailed features of the Duckfoot pattern, it seems clear that the north margin of Ice Stream G shifted inward with an accompanying change in flow direction. As it did so, ice from the area between the two margins did not stagnate immediately, and parts of it were sheared and folded by flow along the new direction of motion before stagnation. The lack of any substantial difference in the surface texture of the two regions suggests that the margin shift did not appreciably precede the shutdown of $\mathrm{C}$, but we infer that the outer margin is older, because of the clear presence of the inner one and the presence of shearing between the two. Presumably, all flow traces of Duckfoot would have vanished if that area had been part of an active ice stream. Burial depths of the near-surface crevasses would give an estimate of the time since cessation of motion in each section, but the crevasses are too shallow for any of them to be resolved with the lowfrequency radar.

The compressive strain rate observed across the lower part of the dome flank implies that this area must be thickening considerably, probably as a direct result of the shutdown and the thickening of Ice Stream C. Nereson (1998) investigates what may be learned regarding the timing of the shutdown of an ice stream from the rate of thickening of the adjacent ridge. According to this analysis, a wave of thickening, which travels faster than the ice, causes small topographic features associated with the former margin of an ice stream to be lifted onto the flank of the ridge. As the dome reaches a new steady state, ice flow carries the feature downslope. When applied to Siple Dome, models of this process show that the outermost Duckfoot scar is within the initial stages of this rise, and that the inferred thickening-rate pattern from the horizontal GPS flow field for the south flank of Siple Dome is most consistent with a margin shutdown approximately 300-500 years BP (Nereson, 1998, 2000).

While it is useful in placing constraints on the timing of ice-stream shutdown, the above discussion of the Duckfoot area does not fully explain the present-day topographic profile or the velocities across the Duckfoot feature. Instead of being perched on a plateau or gently sloping dome flank, the outermost, oldest scar is adjacent to a broad trough, with $\mathrm{a} \sim 15 \mathrm{~m}$ rise between it and the most recent margin of Ice Stream C. At this time we have no completely satisfactory explanation for this profile, though several hypotheses seem reasonable. The rise may represent a remnant bulge from flow over a sticky spot; it may be due to melting or flow of warmer, softer adjacent ice as a result of shear during its active period; or it may represent a spatial variation in accumulation across the region.

Returning to Figure 6, we propose a likely scenario of what has happened in light of the preceding discussion. If the outer scar is the former ice-stream margin, as seems likely, region 3 must have been part of Ice Stream C that became partially deformed as it stagnated and the margin shifted south to its new location. Instead of the margin jumping cleanly from the scar to the eventual location and leaving completely stagnated ice behind, some motion within this region began along the new flow direction, shearing and warping parts of the former ice stream before motion stopped completely. Region 3, exhibiting well-defined internal layers, is the least deformed section of former icestream ice situated between areas of higher shear underly- 


\section{NORTH C MARGIN}

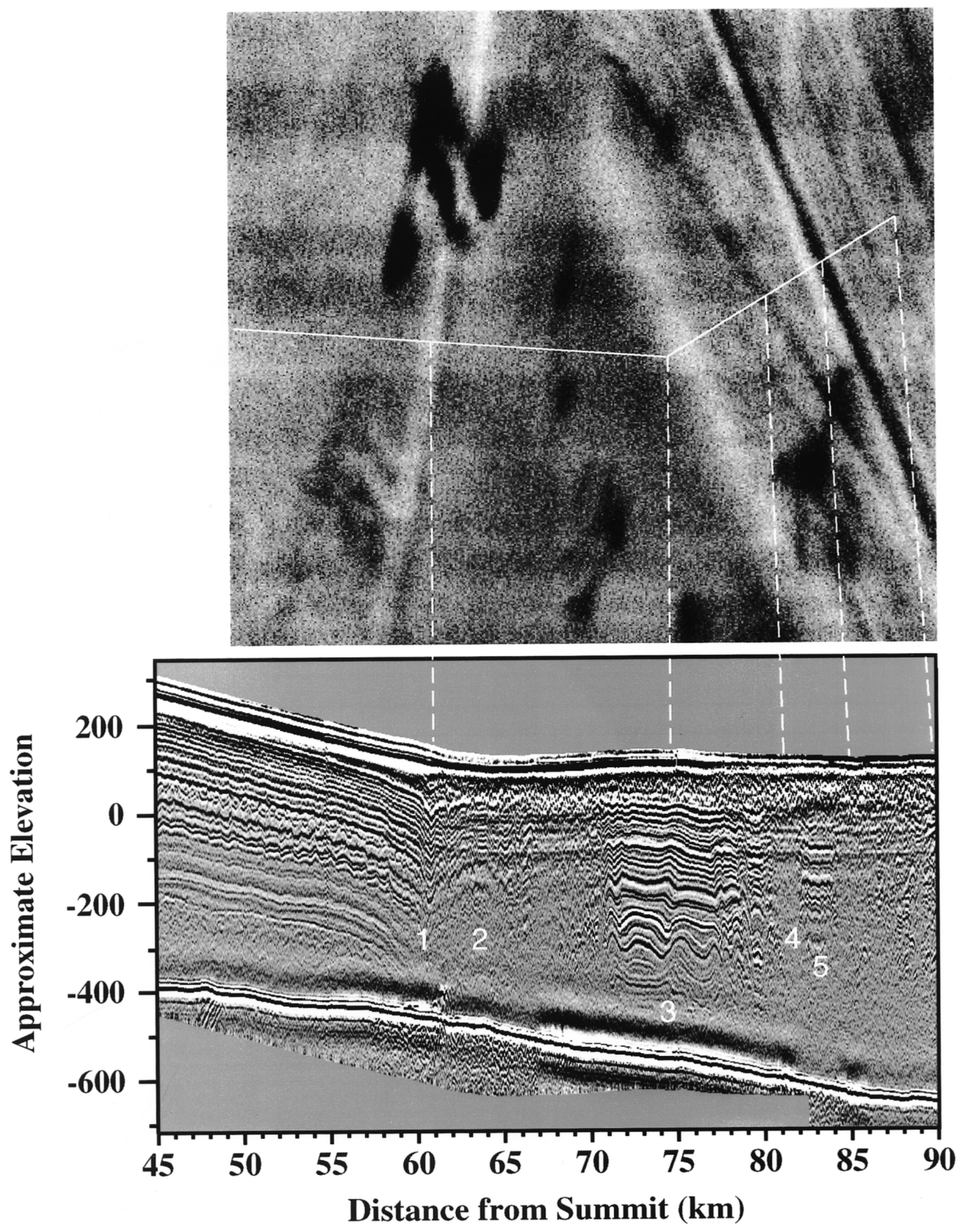

Fig. 6. Part of the Landsat image of Figure 4 (upper panel) together with a detail of the $5 \mathrm{MHz}$ radar profile across the Duckfoot area (lower panel) at the same horizontal scale. Vertical scale in the lower panel is approximate meters above mean sea level. Distance is km from Siple Dome summit and corresponds to the coordinates in Figure 3. Numbers within the internal layer pattern refer to zones described in the text. 
ing the outer margin to the north (regions 1 and 2) and the shear folds to the south (region 4).

The second zone of well-defined internal layers along the traverse (region 5, km 82-84) lies below the narrowing triangular region on the surface in Figure 6 , bounded by the most prominent flowband to the north and the recent margin of Ice Stream C. In the scenario just described, this too is ice which was part of Ice Stream $\mathrm{G}$ before the margin shifted, but it was evidently subject to less shear than neighboring ice directly beneath the shear folds. When this narrow zone of ice stagnated, the margin transition was complete and the new shear margin developed to the south.

Figure 7 shows a sketch of the time sequence of changes in flow which could lead to the observed pattern of flow traces and margin scars of the Duckfoot. In this scenario, change in the north margin of Ice Stream $\mathrm{C}$ was a response to the stagnation of a region of ice located near the margin, approximately centered at what is today the Duckfoot. This area may have behaved something like the "sticky spots" seen today in ice streams, but located near the margin. Ice flowing toward this stagnated region was diverted some $20^{\circ}$ toward the center of the ice stream. As ice began to flow around the stagnated area, shear-folding of former flow bands was initiated at the upstream end, creating a diffuse zone of shear and a new margin (center panel). The icestream boundary adjusted to this slightly enlarged area of stagnation by once more shifting inboard and creating the narrowing triangle defined by the shear folds and the nascent margin (lower panel). Variations on this sequence of events, or alternative explanations, are of course possible, but this seems at present the most plausible scenario linking the imagery, radar and GPS observations.

Our scenario proposes that the surface features we see on the north side of Ice Stream C are the result of a widening stagnation of a triangular-shaped area of ice just inside the older margin. The root causes of this stagnation are not yet clear, but we consider three possibilities: (1) a general reduction in water pressure under Ice Stream $\mathrm{C}$ which causes the largest proportional increase in effective normal stress at the bed in this marginal zone because the ice is thin there; (2) reduced velocity in Ice Stream $\mathrm{C}$ which reduces the drag on this margin from the central parts of the ice stream; (3)
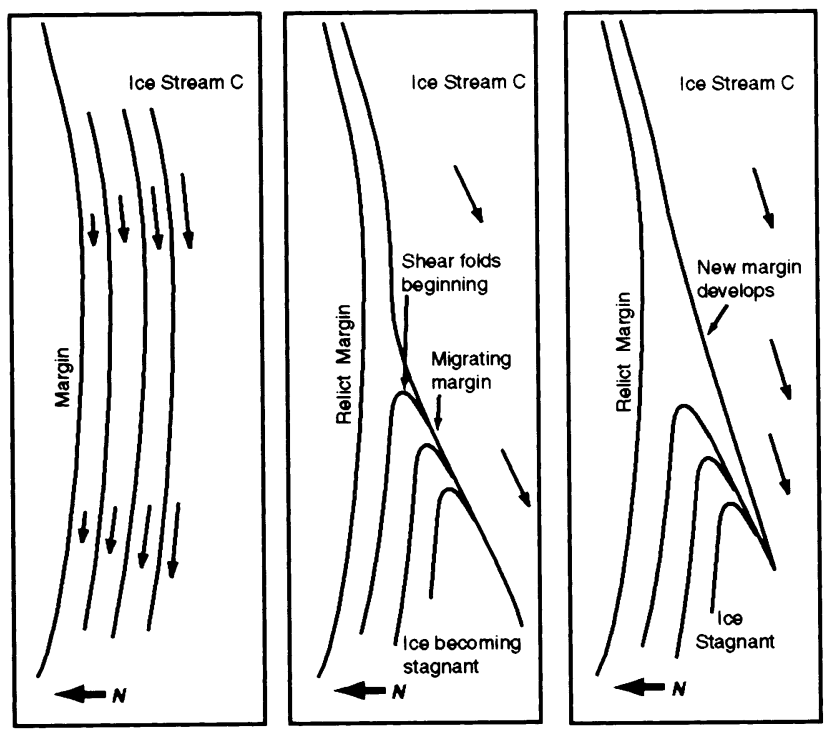

Fig. 7. Time sequence showing likely evolution of the north margin of Ice Stream $C$. onset of freezing associated with a general thinning of Ice Stream $\mathrm{C}$ which will have the strongest and most rapid effect where the ice is thin.

Basal water-pressure variations beneath an ice sheet are controlled primarily by surface slope $(\sim 90 \%)$ and secondarily by bed slope $(10 \%)$. In the vicinity of the Duckfoot, bed slope is considerably greater than surface slope $(\sim 1 \%$, vs near-zero at the surface), with the bed sloping down toward the stream center (Fig. 6). Therefore, water pressure in a connected system at the bed would decrease rapidly from the center trunk towards the margin, thereby increasing the effective normal stress. In a regime of declining basal water pressure this area might be expected to be the first to stagnate, as the uncompensated overburden pressure of ice resting on the bed increased.

However, recent studies regarding the downwarped pattern of internal reflectors near ice-stream margins, and calculations of the heat production due to shearing in margin zones, have led to the conclusion that ice-stream shear zones may generate water by melting near the bed (Jacobson and Raymond, 1998). Thus, the older margin itself was a likely source of water contributing to basal water pressure. If that water production declined due to a slowdown of the ice stream, the reduced water production could lead to reduced water pressure in the sub-ice hydrologic system, and stagnation along the bed slope beneath the Duckfoot.

Basal freezing has also been discussed as a mechanism for inward migration of an ice-stream margin (Jacobson and Raymond, 1998). In the steady-state situation, shear heating and basal melt inside the ice stream are balanced by conductive losses to the surface and the influx of colder ridge ice from outside the margin. If the ice thickness at the margin is reduced, or if the margin migrates to an area of thinner ice, the resulting increase in temperature gradient provides a way to drain heat more effectively from the bed, and freezing occurs. As may be seen from Figure 2, the ice beneath the Duckfoot is quite thin for an ice stream (500$700 \mathrm{~m}$ ), so heat loss and freezing due to changes in the geothermal gradient should occur first here.

The sequence of events at the Duckfoot and the mechanisms which caused it may have counterparts elsewhere within the Siple Coast drainage system. Changes at the downstream end of Ridge B/C (Fig. 1) appear to indicate a similar area of stagnation with a narrowing of the south margin of Ice Stream C. Bindschadler and Vornberger (1998) have described a recent widening of the north margin of Ice Stream B in this same area, from a comparison of newly released U.S. Department of Defense imagery from the 1960s and more recent Système probatoire pour l'observation de la terre (SPOT) imagery. Yet Figure 1 suggests that this margin too may have narrowed in the more distant past, leaving a tongue of stagnant ice at the downstream end of Ridge $\mathrm{B} / \mathrm{C}$.

The possible relationship of changes in the margin of Ice Stream G at the Duckfoot to the shutdown of Siple Ice Stream also deserves comment. Recent radar studies by the University of Wisconsin and the University of Washington place the shutdown time of Siple Ice Stream near 420 years BP, based on the burial depth of disturbed layers (Smith and others, in press; personal communication from A. M. Gades, 1998). The approximate date for the shift in the north margin of Ice Stream C at the Duckfoot, based on model studies, is on this same order. With the information currently available we can say no more about a possible con- 
nection between these events. However, enhanced Landsat imagery shows clearly that motion in the main trunk of Ice Stream C postdates the shutdown of Siple Ice Stream. This is evident from the tails of flow bands streaming north into Siple Ice Stream which have been sheared and truncated by more recent flow in Ice Stream C (Jacobel and others, 1996a, fig. 3).

\section{CONCLUSIONS}

The shutdown of Ice Stream C appears to have been a more complex set of events than might have been foreseen based on early studies of the south margin. Evidence from the Duckfoot area shows that the position of the north margin of Ice Stream C changed at least once prior to the most recent shutdown of the main trunk $\sim 150$ years BP. Probably 300500 years BP, the margin shifted southward in a sequence of events that involved stagnation and shear-folding of former parts of the ice stream. With the present study we are unable to place better limits on timing of the changes, but further information could come from a high-frequency radar traverse to measure the burial depth of crevasses to place better constraints on the ages of the events at the Duckfoot.

Considering these changes in a regional context, perhaps as recently as 450 years ago ice traversed the northeast flank of Siple Dome in the relict Siple Ice Stream. The possible relationship of this shutdown to changes at the Duckfoot is not yet clear, but the estimates of timing are close to overlap. It is clear, however, that motion in the lower trunk of Ice Stream $\mathrm{C}$ postdates the shutdown of Siple Ice Stream, so that at least part of Ice Stream $\mathrm{C}$ was active after that time.

\section{ACKNOWLEDGEMENTS}

We would like to acknowledge C. Shuman and Xin Chen who measured GPS positions of the strain grid in 1997. This project was supported by grants from the U.S. National Science Foundation: OPP 9316338 to St Olaf College, OPP 9316807 to the University of Washington and OPP 9317007 to the National Snow and Ice Data Center, University of Colorado, Boulder.

\section{REFERENGES}

Alley, R. B. and I. M. Whillans. 1991. Changes in the West Antarctic ice sheet. Science, 254(5034), 959-963.

Bentley, G. R., P. D. Burkholder, T. S. Clarke, C. Liu and N. Lord. 1994. Geophysical experiments on Ridge B1/B2, Siple Coast. Antarct. F. U.S., 29(5), Review 1994, 57-59.

Bindschadler, R. A. 1998. Future of the West Antarctic ice sheet. Science, 282(5388), 428-429.

Bindschadler, R. A. and P. L. Vornberger. 1990. AVHRR imagery reveals Antarctic ice dynamics. EOS, 71 (23), 741-742.

Bindschadler, R. and P. Vornberger. 1998. Changes in the West Antarctic ice sheet since 1963 from declassified satellite photography. Science, 279(5351), 689-692.
Bohlander, J. A. and T. A. Scambos. 1997. Ice velocity of Ice Stream D, F, and the Shirase Coast: flow dynamics and changes. [Abstract.] EOS, 78(46), Fall Meeting Supplement, F252.

Casassa, G., K. C. Jezek, J. Turner and I. M. Whillans. 1991. Relict flow stripes on the Ross Ice Shelf. Ann. Glaciol., 15, 132-138.

Conway, H. and A. M. Gades. In press. Glacial history of Roosevelt Island, West Antarctica. In Bindschadler, R. A., ed. The West Antarctic ice sheet. Chapman Conference, 13-18 September 1998, Orono, Maine. Washington, DC, American Geophysical Union.

Gades, A. M. 1998. Spatial and temporal variations of basal conditions beneath glaciers and ice sheets inferred from radio echo soundings. (Ph.D. thesis, University of Washington.)

Jacobel, R.W., A. M. Gades, D. L. Gottschling, S. M. Hodge and D. L. Wright. 1993. Interpretation of radar-detected internal layer folding in West Antarctic ice streams. F. Glaciol., 39(133), 528-537.

Jacobel, R.W., T. A. Scambos, C. F. Raymond and A. M. Gades. 1996a. Changes in the configuration of ice stream flow from the West Antarctic ice sheet. F. Geophys. Res., 101 (B3), 5499-5504.

Jacobel, R.W., A. J. Fisher and N. M. Sundell. 1996b. Internal stratigraphy from ground-based radar studies at Siple Dome summit. Antarct. F. U.S., 31(5), Review 1996, 55-56.

Jacobson, H. P. and C. F. Raymond. 1998. Thermal effects on the location of ice stream margins. F. Geophys. Res., 103(B6), 12,111-12,122.

Kvaran, G., T. Scambos and M. A. Fahnestock. 1996. Improved AVHRR imagery of ice sheets via data cumulation - a theoretical and empirical validation. [Abstract.] EOS, 77(46), Fall Meeting Supplement, F193.

Nereson, N. A. 1998. The flow history of Siple Dome and Ice Streams C and D, West Antarctica: inferences from geophysical measurements and ice flow models. (Ph.D. thesis, University of Washington.)

Nereson, N. A. 2000. Elevation of ice stream margin scars after stagnation. f. Glaciol., 46(152), 111-118.

Nereson, N. A., E. D. Waddington, C. F. Raymond and H. P. Jacobson. 1996. Predicted age-depth scales for Siple Dome and inland WAIS ice cores in West Antarctica. Geophys. Res. Lett., 23(22), 3163-3166.

Nereson, N. A., C. F. Raymond, E. D. Waddington and R. W. Jacobel. 1998a. Migration of the Siple Dome ice divide, West Antarctica. 7. Glaciol., 44(148), 643-652.

Nereson, N. A., R. C. A. Hindmarsh and C. F. Raymond. 1998b. Sensitivity of the divide position at Siple Dome, West Antarctica, to boundary forcing. Ann. Glaciol., 27, 207-214.

Orheim, O. and B. K. Lucchitta. 1987. Snow and ice studies by Thematic Mapper and multispectral scanner Landsat images. Ann. Glaciol., 9, 109-118.

Raymond, C. F., N. A. Nereson, A. M. Gades, H. Conway, R. Jacobel andT. Scambos. 1995. Geometry and stratigraphy of Siple Dome, Antarctica. Antarct. 7. U.S., 30 (5), Review 1995, 91-93.

Raymond, C. F., R.W. Jacobel, T. A. Scambos, N. A. Nereson and H. P. Jacobson. 1997. Energy balance of ice streams and melting at margins. [Abstract.] EOS, 78(46), Fall Meeting Supplement, F243-F244.

Retzlaff, R. and C. R. Bentley. 1993. Timing of stagnation of Ice Stream C, West Antarctica, from short-pulse radar studies of buried surface crevasses. f. Glaciol., 39(133), 553-561.

Scambos, T. A. and R. A. Bindschadler. 1991. Feature maps of Ice Streams C, D and E, West Antarctica. Antarct. F. U.S., 26(5), 312-314.

Scambos, T. A. and N. A. Nereson. 1996. Satellite image and GPS study of the morphology of Siple Dome, Antarctica. Antarct. F. U.S., 30(5), Review 1995, 87-89.

Shabtaie, S. and C. R. Bentley. 1987. West Antarctic ice streams draining into the Ross Ice Shelf: configuration and mass balance. 7. Geophys. Res., 92(B2), 1311-1336. (Erratum: 7. Geophys. Res., 1987, 92(B9), 9451.)

Smith, B. E., N. Lord and C. R. Bentley. In press. Ground based radar study of the stagnation of Ice Stream C and the Siple Ice Stream, West Antarctica. In Bindschadler, R. A., ed. The West Antarctic ice sheet. Chapman Conference, 13-18 September 1998, Orono, Maine. Washington, DC, American Geophysical Union.

Stephenson, S. N. and R. A. Bindschadler. 1988. Observed velocity fluctuations on a major Antarctic ice stream. Nature, 334(6184), 695-697. 